\title{
The Impact of Cultural Diversity on Economic Development in Saudi Arabia - Empirical Study
}

\author{
Hanaa Abdelaty Hasan Esmail ${ }^{1}$ \\ ${ }^{1}$ Thebes Higher Institute of Computer and Management Sciences, Thebes Academy, Department of Economic, \\ Cairo, Egypt \\ Correspondence: Hanaa Abdelaty Hasan Esmail, Thebes Higher Institute of Computer and Management \\ Sciences, Thebes Academy, Department of Economic, Cairo, Egypt. E-mail: Hanaa_adelaty001@yahoo.com
}

Received: February 8, 2019

doi:10.5539/jsd.v12n2p70

\author{
Accepted: February 26, 2019 Online Published: March 30, 2019 \\ URL: https://doi.org/10.5539/jsd.v12n2p70
}

\begin{abstract}
Ideas and beliefs play an important role in guiding human behavior. As culture has a clear impact on community development, intellectual change or cultural change will rebuild Saudi society.

For this purpose, our study dealt with a presentation of the various previous studies that clarified the role of cultures in the development of society and whether change and diversity have a clear role in development.

The study was based on a survey of a group of questions to members of the community where the questionnaire was distributed to the University community to take different views of gender. The study also focused on determining the role of cultural diversity and emerging from some old customs to achieve sustainable development which is represented in three main dimensions of economic development, social development and finally political development. Assumptions were analyzed using multiple regressions.
\end{abstract}

Keywords: culture, development, society, questionnaire, human resource, industries

\section{Introduction}

In previous eras, economic development was seen as a development of production and employment. It is also viewed with its relation to the industrial and agricultural status of the state even also improving services in any country. This is in addition to the ideas of many sociologists who explained the phenomenon of self-sufficiency and development and the extent to which it is related to the cultures of peoples.

The society must have the ability to extract the means that will drive it to economic development. Among these means there is cultural development, which has a very important role in promoting and making effective changes in society. Cultures have a critical role to play in the development and success of their programs.

Saudi Arabia has natural resources such as oil as well as human resources; however there is a problem in the development of many sectors. That may be due to the diversity of ideas and the existence of some beliefs that negatively affect the development. Improving the quality of life is not only related to the availability of natural resources and money, but also needs a civilized economic thought that should be away from the old beliefs that have not changed from ancient times.

According to the culture of some traditional societies, we find that the culture has influential role in their development because it is an obstacle to the growth and advancement of projects. Many economic problems can be solved if people understand the nature of the problem and how to overcome it. The importance of culture and its relationship to economic development is due to the need for societies to believe in the necessity of changing many ideas and beliefs that will have a positive impact. This will only be achieved through the participation of societies in cultural change.

The study of the relationship between culture and development necessitates research and analysis of the customs and traditions of the Kingdom of Saudi Arabia as a center for study and know the extent of their response to community development. The development of traditional societies and the change of some cultures are very difficult and may cause fail to development projects. For example, many of Southwest Asia's economies are moving in a development direction and record huge growth rates whether compared to some countries.

There is no doubt that culture plays a role in development and changes in culture as a result of its positive effects 
to serve the purposes of comprehensive development. Saudi Arabia has remained more than 40 years without changing its beliefs about the role of women economically and even the subject of driving cars. What is certain now is that the trend towards attention to the role of culture requires many encouragements and do not think that the failure of any state for any reason whether religious or even factors of scarcity of resources.

Our study asks an important question; why does economic development depend on the cultural change of the Saudi society? We can answer this question by knowing the role of cultural development in promoting economic growth.

In order to answer this question, diversity and cultural industries must find their role in accepting the society as well as the intellectual openness of the society and acceptance of many changes. This is what our questionnaire presented in this paper.

To answer the question posed by our study. We can determine culture as an engine for economic development in Saudi Arabia through knowledge of fundamental forces which is an obstacle to the development of cultural awareness and investment in cultural industries. Then, we can identify the impact of cultural diversity on society economically and socially and their acceptance of that diversity.

There are some countries that have proved this including China which has made this practical, as well as America, which relied on the economics of culture which is considered the second largest industry after the manufacture of weapons become cultural industries which add more than $25 \%$ to GDP.

Changing ideas and beliefs in Saudi Arabia has begun to take a positive path towards intellectual openness. In this context, Allen Scott (2001) focused on the importance of culture as an urban product. In other words, those industries create an environment based on tourism, entertainment, media, etc.

On the other hand, cultural industries are related to social development represented in the creation and revitalization of the labor market, where demand for such goods and services is affecting social development (EDURC 1997).

\section{Literature Review}

Adam Smith (1759) was the first scientists who took into consideration the cultural thought. He analyzed the customs, traditions and their fundamental role in developmental thought. Also Max Weber (1930) focused on the role of ethics and its effect in the growth of capitalism in Europe. And by the end of the nineteenth decade we find Lawrence Haarrison (1985) interested with culture and its role in developing societies who presented a book entitled "Under development is state of mind - a case study of Latin America" which concluded that the backwardness of the nations is due to their old ideas and beliefs.

On the other hand, Jim Granato et al (1996) merged the cultural variables into economic growth model where analyzed the effect of culture on economic growth in 25 countries by using OLS to test the role of cultural factors on economic growth. Also, Joseph Ato Forson et al (2013) tested the value of culture and its effect on economic growth by using an input and output growth model.

Kgosietsile Maripe (2012) pointed out that ancient culture must be protected and strengthened. The study has concluded that culture plays an important role in achieving social and economic stability. Also P. E. Petrakis (2011) examined the relationship between development and culture with special reference to the state of Greece. His study analyzed the differences between the Mediterranean countries and the countries of Northern Europe. The result referring to this study showed countries do not look at future development. Besides, he found cultural development is reflected in the basic characteristics of the economic and trade environment.

Olayinka Akanle (2012) described through literature how development in the past leads to development in the present and future. This paper described the accuracy of cultural diversity in Nigeria which influenced development.

In the field of culture of creativity and innovation Sviatlana Buloichyk (2010) described the main cultural institutions and their role in creating economic conditions and the development of labor as a mean of innovation in enterprises. Also he added some conditions and factors to achieve the desired economic development as a method of financing as well. In contrast, Titan et al (2013) focused on the analytical approach to measure culture as one of the most important tools that could add to the national income. The relationship between the variables that distinguish the cultural and creative field in many European countries was analyzed using Linear Regression Model and reached to the effect of consumption by income.

On the other hand Gavrilescu et al (2010) assessed the culture related to dealing with employed by using surveys .The study concluded the need to emphasize rational behavior and experience in the management of 
hospitals and the need to understand the cultures of individuals in each country so that they can develop the appropriate strategy.

Most of studies have an evidence for evaluation the meaning of culture so UNESCO $(1966 ; 1982)$ focused on link international cooperation between countries based on their culture levels and described culture as having the physical, intellectual and emotional qualities which distinguish this human group along with art, literature and ways of life. Also, Cuerzoni (1998) described the culture as activities or production consisting of cultural goods and services.

Taking into account the vital and complex role of culture within society, we find Brigit Stober (2011) discovered many central aspects of culture and how to use it as a strategic tool to build and develop the region. Also, Tom O'Dell (2009) described the culture and the possibility of using research related to culture and its history. This is besides identifying the relationship between culture and economic at the present.

Godwin Okaneme (2015) attributed the components of development to three factors language, culture, and knowing reading and writing. Research pointed out that culture is the main factor and it is indispensable to any society. Both researchers, Zuofa (2006), Obiegbu Lifeyinwa, (2016) have agreed in the same opinion.

In the relationship between culture and social development, Ramirez L.Felipe et.al (2016) showed the positive factors of culture and its role in the development of South Korea. The author confirmed the need for an inevitable relationship between the social conditions and culture of the country. To study the entanglement between social development and culture A. Iyaji, T.I. Gomment (2011) confirmed that human life or human beings are the basis for development.

Moreover, Chunyan Shao (2009) analyzed the relationship between the creative culture and sustainable development through assessment of the innovative culture that will increase the competition between institutions to achieve development.

There are studies that link the happiness of the individual consumption of many cultural industries. Where EDURC (1997) examined the role of consuming many cultural goods and services with happiness, the result refers to the average age of the individual increases with the consumption of cultural industries.

In addition to that, Xiufang li (2015) described how to structure the culture of minorities during social transformation period used quantitative analysis method to understand and analyze local culture and understand their psychological activities. Also, there are so many countries that have nurtured children culturally since childhood. Aparkumar lamsal (2013) cultivated the idea of a culture of interest to children as a turning point in society during the growth phase. Also, Dana Irina (2011) focused on the concept of culture, describing the culture as a comprehensive description and explaining that there is a need to take care of culture and consider it among the basics of human rights.

Finally, European literature in the 20th century defined culture as the source of civilizations. Also, Yan Luo (2009) classified culture levels according to definitions. Researcher has been classified it into three types. The first type is represented in total culture shared by persons of the same nationality. The second type is represented in a small culture. This is shared by small groups such as tribes. The third type represents culture that related to a professional group within the total cultures.

\section{Discussion}

\subsection{The Relationship between Culture and Development}

In the past, the wealth of nations was measured by gold and minerals until economists realized the need to employ these resources. There were many issues and ideas for economic development.

Economic development is shown as economic growth that is accompanied by a change and this change may be social or cultural. Economic development includes the change that takes place from material and intangible aspects such as science, art, philosophy, technology, tastes, language and all cultural changes that occur in society as a whole. Cultural development, which makes the individual as a human resource the base of society, affects positively or negatively the economic development. There is an evidence of the role of culture in economic development evidenced during the financial crisis between 2008 and 2011 when the revealed United States of America paid attention to the culture sector believing that there is an impact on job creation.

Even the French economy has been positively influenced by the role of cultural industries, the cultural sector contribute with $5 \%$ of GDP (Note 1), Not only America and France give importance to the cultural sector and its obvious impact on the country's GDP, but also the South Korean model bet on the success of cultural creativity and its development role. Since 1993, cultural industries have been considered one of the pillars of the 
economy. The question that we can impose in this paper is whether culture has an effective role in activating development programs in Saudi Arabia or not?

The current cultural situation in Saudi Arabia shows the absence of cultural projects or investments that would add to GDP. Also, improving the individual's outcome will drive growth and economic development.

Culture will have importance as an engine for the urban development of Saudi Arabia if the interest of cultural industries has an economic power like many countries of the world. If we look at the education sector, especially the private sector based on achieving the maximum profit possible, we will find it one of the most important cultural organizations driving the economy. This makes us ask why the rest of the cultural industries are not being relied on to generate income and create different areas of work in the cultural organizations such as cinemas and theaters as cultural activities.

There is no doubt that culture has a role in generating different economies for its importance in improving the quality of life. Therefore, our questionnaire includes the extent to which members of society accept or reject the idea of cultural diversity and the trend towards cultural industries.

Furthermore, culture contributes to community balance and urban development. It gives space for the intellectual development of the human element and even interaction with the rest of the world. The Saudi investor can invest in many cultural facilities which increase the strength of the knowledge of economy in Saudi Arabia. Giving more attention to cultural industries as a mean of development that generates income for many countries in the form of services needed by society will have a developmental impact as (Florida 2000) explained in his study which explains the relationship between culture and economy.

Since Saudi Arabia is pursuing many reforms to reach a new vision by 2030. Cultural industries had to be included among their priorities, for example, knowledge based on creativity, art and investments in the theater and cinema activities that related to the knowledge economy will have an important role in achieving economic development.

In the past, business was conducted according to the comparative advantage theory of each country where each country specializes in producing goods or services to exchange them with another country. But now, the intellectual aspects have the role of production and growth. For example, Japan, which relied on the production of children's toys and animation, as well as, the American economy, which relied on cultural industries. This means culture has contributed to the emergence of new production patterns that reflect their cultures, creativity and innovation in production

Recently, economists have been interested in cultural thought and linking it with economic development. Also, Arab and Islamic countries are interested in culture as an important role in the development.

There is no doubt that the attention to the role of culture as a factor affecting the economic and social development in the Arab and Islamic countries has increased. We do not think there is much disagreement about the importance of this role in the region's backwardness. This importance may be more prominent in Muslim countries. It is also difficult to trace the backwardness of the region to purely economic factors, such as the abundance of natural resources, or the scarcity of capital, for example, while most of these countries have sufficient oil.

All kinds of development is considered a means and objective to achieve the renaissance of society and provide a better life, culture is one of the most important factors contributing to the success of development programs as it has a fundamental role in guiding the individual's behavior towards economic and social progress.

It is clear that unprecedented intellectual mobility and cultural awareness will lead to the success of 2030 Vision in the case of the integration of Saudi women in various economic, social and political fields, but women's political participation remains low in most regions of Saudi Arabia. This relative absence of women is due to intellectual and cultural obstacles since ancient times, which prevents the achievement of equality and this reference cultural heritage and traditions that stopped the contribution of Saudi women.

Saudi culture includes a negative view of the role of women politically, where they have been isolated and defined roles in work that are completely different from the roles of men, although Saudi women recently have qualified, and they are able to participate in various fields

After more than 40 years and according to the new vision of the development. We observed a new cultural diversity directed towards the plans and programs of development desired by the wise leadership of King Mohammed bin Salman, without any community role in that.

Regarding to the Human Development Report, we can reach to the cultural dimension of development which 
illustrates the relationship between economic growth and human development. Thus, we can analyze the relationship of culture to the concept of development through the concept of human development which is divided into three main components:

1) Human capabilities such as education, training and rehabilitation of human capital.

2) Recruitment of human capability in the production.

3) The level of well-being achieved based on human potential and the possibility of benefiting from it in social, economic and political activities

Each society has its culture and beliefs that are difficult to change, but it has to be taken into account the role of individual to show the creativity or ideas regard less of the individual male or female. So we can make it clear that cultural diversity is one of the fundamentals of economic and human development.

Culture can be defined as the sum of the values and behaviors of the human element which are directed by the individual in all aspects of life as social, political or economic. As the level of economic and social growth is influenced by the culture of society and many of the practices of the individual in the community have reflected positively or have inverse on the development process.

Therefore, we can conclude that different cultural patterns and their diversity are the path to development. It has become important to pay attention to women and their role in the development of society. There are so many ideas and thoughts have appeared in society as the emergence of influential decisions in economic development such as the decision of women driving the car which has been rejected for more than 40 years. It is, therefore, possible to change the thinking and culture of society about the marginalization of the role of women and the need to recognize its value and role in society.

Recently, in Saudi Arabia, there has been a trend toward correcting some of the situation; the rulers' direction has become clear and urgent for the comprehensive development that focuses on the development of human resources without distinction between men and women.

If we consider that education sector is the basis of culture and cultural development in Saudi Arabia, we will be able to have a dynamic and reciprocal relationship between development and education on the basis that education is a driving force for comprehensive development. Moreover, by linking cultural development with education, it can be pointed out that culture is the behavioral and intellectual patterns that achieve the desired development.

So, creativity is considered among the cultural industries. It is also a driving force in market development and that there is a need to produce culture for the market as explained by Scoot (2000).

Not only education but also technology and creative skills have an influential role to achieve economic development as they have a positive effect on production methods. This confirms that the human resources and its knowledge, attitudes, values, skills and innovative abilities are the basis determinates for achieving economic and social progress. Development of human resources has a clear role in enriching development in all economic activities. We can sum that development is as community process directed to create structural transformations and social, economic and political changes that would allow improving the quality of life and preparing the society to continue its civilized aspirations. All of this can happen and lead to independent development of the community when it is able to disrupt dependency.

\section{Methodology and Hypothesis}

Our study is descriptive analytical method as an approach to the overall analysis by relying on the questionnaire prepared for this study, as well as analyzing all the data using the appropriate statistical methods to address them.

Based on the above discussion on the subject of culture in Saudi Arabia and its impact on economic development and related studies especially after the adoption of many decisions, which is a breakthrough for the thought of civilized development in Saudi Arabia.

Therefore, the higher education sector, especially the Business College of Administration in Jizan University, has been selected to publish the questionnaire through it. The questionnaire was designed to consist of 49 questions. The questionnaire included three main sections, the first section aims to know the role of cultural diversity in economic development, the second section focuses on the role of cultural diversity in social development, and the last section which reflects the relationship of cultural diversity to the political awareness of individuals.

The study assumes the following hypothesis: -

1) First - H0: There is no significant relationship between cultural diversity and economic development. 
H1: There is significant relationship between cultural diversity and economic development.

2) Second- H0: There is no relationship between cultural diversity and social development.

H1: There is relationship between the level of cultural diversity and social development.

3) Third- H0: There is no statistically significant relationship between cultural diversity and political development.

H1 There is statistically significant relationship between cultural diversity and political development

\section{Analysis and Discussion of Results}

(1) To measure the reliability of study tool, the Alpha Cronbach method was used to verify the credibility of the sample before the questionnaire was presented to the entire community, where the coefficient of reliability is $0.90 \%$ as is illustrated in the table (1). This means that most of questions were formulated in a clear way and it is possible to distribute the questionnaire to the entire sample.

(2) To measure reliability for each dimension separately after adjusting some of the questions required according the opinions of the consultant of sample.

Table 1.

\begin{tabular}{ccccc}
\hline Name of variable & Economic. Reliability & Social. Reliability & Political. Reliability & Full Questionnaire Reliability \\
\hline Alpha Cronpach & 90.5 & 87.2 & 87.8 & 94.1 \\
\hline
\end{tabular}

It is noted from the table that reliability coefficients for all variables are equal to $94 \%$, this value is acceptable and confirms the stability and reliability of the sample for all dimensions in the field application of the study.

Also the result infers the level of responses, whether accepted, rejected, or neutral through the estimated balance of the sample. The number of rejected responses is expressed as low which are limited to 1:2.59, The number of neutral responses is expressed as neutral which are limited to $2.60: 3.39$ And the number of accepted responses is expressed as high which are limited to $3.40: 5$. 
Table 2. The result of economic dimension

\begin{tabular}{|c|c|c|c|}
\hline Item & Mean & $\begin{array}{l}\text { Std. } \\
\text { Deviation }\end{array}$ & level \\
\hline Q1:From your point of view culture and economy are two sides of a single coin & 3.63 & .890 & high \\
\hline Q2: Economic growth influenced by the culture of society & 3.91 & .901 & high \\
\hline Q3: Culture has an engine for economic development & 4.07 & .751 & high \\
\hline Q4: Changing cultural thought will affect consumer rational & 3.84 & .916 & high \\
\hline $\begin{array}{l}\text { Q5: Saudi Arabia dependence on alternative sources of income for oil will be the } \\
\text { first cultural change }\end{array}$ & 3.75 & .989 & high \\
\hline $\begin{array}{l}\text { Q6: Cultural changes taking place in the Kingdom of Saudi Arabia contribute to } \\
\text { the treatment of economic problems }\end{array}$ & 3.84 & .924 & high \\
\hline Q7: Cultural diversity will promote economic development & 3.96 & .820 & high \\
\hline Q8: Women's empowerment have an active role in economic development & 4.08 & .916 & high \\
\hline Q9: Wise decisions contribute to economic growth & 3.95 & .864 & high \\
\hline $\begin{array}{l}\text { Q10: Women's drive will positively affect the mobility of economic } \\
\text { development }\end{array}$ & 3.62 & 1.169 & high \\
\hline Q11:Cultural development role in future policy-making to reach the 2030 vision & 4.00 & .825 & high \\
\hline $\begin{array}{l}\text { Q12:Empowerment of women for all professions and not restricting them to } \\
\text { occupations without others has a role in economic development }\end{array}$ & 3.80 & 1.032 & high \\
\hline $\begin{array}{l}\text { Q13:Development projects in the Kingdom of Saudi Arabia are affected by } \\
\text { cultural heritage }\end{array}$ & 3.56 & .932 & high \\
\hline $\begin{array}{l}\text { Q14:Gradual cultural change contributes to an increase in the rate of economic } \\
\text { growth }\end{array}$ & 3.87 & .834 & high \\
\hline $\begin{array}{l}\text { Q15:The cultural development in Saudi Arabia will contribute to the success } \\
\text { of } 2030 \text { Vision }\end{array}$ & 4.07 & .839 & high \\
\hline Q16:Cultural development has a positive role to increase GDP & 3.91 & .858 & high \\
\hline $\begin{array}{l}\text { Q17:Cultural development will generate income-generating industries such as } \\
\text { film and theater }\end{array}$ & 3.58 & 1.046 & high \\
\hline $\begin{array}{l}\text { Q18:Cultural development will generate income-generating industries as } \\
\text { publishing for books, magazines and music }\end{array}$ & 3.66 & .964 & high \\
\hline $\begin{array}{l}\text { Q19:The development of creative and innovative thought has a role in economic } \\
\text { development }\end{array}$ & 4.03 & .874 & high \\
\hline Q20:Cultural development creates jobs based on creativity & 4.04 & .825 & high \\
\hline $\begin{array}{l}\text { Q21:Localization of trades and professions will contribute to the economic } \\
\text { development }\end{array}$ & 3.95 & .894 & high \\
\hline Eco Dimension & 3.8634 & .51996 & high \\
\hline
\end{tabular}

Table (2) shows the results of the analysis of the first dimension of development, it is the economic dimension. It consists of 21 questions. The mean of this dimension equal to (3.86). This indicates to the approval of the sample and the possibilities of a relationship between culture and economic development in Saudi Arabia, where the questions No. q(8),(3),(15),(20),(19) were the first rank respectively with mean is equal to 4.08,4.07,4.07,4.04,4.03 in order, while the questions No.q13, 17 were in the last rank respectively with mean equal to 3.58 and 3.56 in order. 
Table 3. The result of social dimension

\begin{tabular}{|c|c|c|c|}
\hline Item & Mean & $\begin{array}{l}\text { Std. } \\
\text { Deviation }\end{array}$ & level \\
\hline Q22: Culture and social status are two sides of a same coin & 3.54 & 1.006 & high \\
\hline $\begin{array}{l}\text { Q23: Customs and traditions such as marriage of more than one wife have a negative } \\
\text { impact on social development }\end{array}$ & 3.57 & 1.163 & high \\
\hline Q24: Diversity of cultures will affect the social patterns of individuals and institutions & 3.59 & .990 & high \\
\hline Q25: Relying on technology has an influential role in the intellectual diversity of society & 3.82 & .931 & high \\
\hline $\begin{array}{l}\text { Q26: From your point of view of the institutes of theater and performing arts as well as } \\
\text { the musical arts influential role in social development }\end{array}$ & 3.46 & 1.086 & high \\
\hline $\begin{array}{l}\text { Q27: The need to change the thought and approach of schools and universities in } \\
\text { accordance with the requirements of cultural development }\end{array}$ & 3.88 & .957 & high \\
\hline $\begin{array}{l}\text { Q28: The need to establish a role for cinema and theater in your city as a kind of cultural } \\
\text { change. }\end{array}$ & 3.57 & 1.209 & high \\
\hline $\begin{array}{l}\text { Q29: Education budgets allocate enough space to culture such as music and arts } \\
\text { education and the establishment of a theater in schools and universities }\end{array}$ & 3.31 & 1.236 & neutral \\
\hline $\begin{array}{l}\text { Q30: From your point of view, cinemas, theater and music have an important role to } \\
\text { develop society }\end{array}$ & 3.21 & 1.228 & neutral \\
\hline Q31: vocational education is an urgent and influential factor in social development & 3.97 & .837 & high \\
\hline $\begin{array}{l}\text { Q32: Create an atmosphere of gender-shared competition in the form of joint task forces } \\
\text { that are conducive to social development }\end{array}$ & 3.70 & 1.095 & high \\
\hline Q33: The decision to drive a woman has positive effects on social development & 3.66 & 1.113 & high \\
\hline $\begin{array}{l}\text { Q34: The availability of art and musical education colleges has an influential role in } \\
\text { society development }\end{array}$ & 3.40 & 1.156 & high \\
\hline Q35: Availability of faculties of physical education for women development requirement & 3.95 & .956 & high \\
\hline Q36: To establish women's sports clubs a role in social development & 3.96 & 1.005 & high \\
\hline Q37: Providing public transport for women is a positive demand for social development & 4.10 & .844 & high \\
\hline Social Dimension & 3.6678 & .59415 & high \\
\hline
\end{tabular}

Table (3) shows the second dimension of social factors and its developmental role which consists of 16 questions. The mean of social dimension was at a high level and closed to 3.66 where mean responses to questions with high levels follows as 4.10,3.97,3.96,3.95, and 3.88 for q37,q31,q36,q35, and q27 are in order. With the exception of q29 and q30, the mean responses were 3.31,3.21 indicating a low mean due to neutral responses to the sample for these two questions. This explains the respondents' reluctance to approve or reject. Because these questions from their point of view out of their habit and traditions which is not as easy to accept. 
Table 4. The result of political dimension

\begin{tabular}{|c|c|c|c|}
\hline Item & Mean & $\begin{array}{l}\text { Std. } \\
\text { Deviation }\end{array}$ & Level \\
\hline Q38: Culture has an influential role in political factors & 3.90 & .865 & high \\
\hline Q39: Cultural development has a positive role in activating state policies & 3.92 & .849 & high \\
\hline $\begin{array}{l}\text { Q40: Cultural differences between the cities of Saudi Arabia and its members will } \\
\text { contribute to the treatment of problems. }\end{array}$ & 3.51 & 1.002 & high \\
\hline $\begin{array}{l}\text { Q41: The diversity of cultures in Saudi Arabia will contribute to freedom of thought } \\
\text { and opinion }\end{array}$ & 3.85 & .897 & high \\
\hline Q42:Culture has an influential role in the political development of Saudi Arabia & 3.97 & .839 & high \\
\hline $\begin{array}{l}\text { Q43:Intellectual and cultural change and diversity will contribute In expressing } \\
\text { opinion }\end{array}$ & 3.89 & .827 & high \\
\hline Q44:International relations and intellectual exchange have a role in cultural change & 3.88 & .846 & high \\
\hline $\begin{array}{l}\text { Q45:Cultural development has advocated the establishment of a parliament to } \\
\text { determine the political role of the growing kingdom }\end{array}$ & 3.59 & .941 & high \\
\hline Q46:Women's access to Parliament is an influential role in political development & 3.57 & 1.047 & high \\
\hline $\begin{array}{l}\text { Q47:Cultural development has a positive impact on political development and its } \\
\text { continued success }\end{array}$ & 3.92 & .826 & high \\
\hline $\begin{array}{l}\text { Q48:The wise decisions in Saudi Arabia to integrate women and give them the right to } \\
\text { drive a car has a positive effect on political development }\end{array}$ & 3.73 & 1.083 & high \\
\hline $\begin{array}{l}\text { Q49:The role of the entertainment to be established in Saudi Arabia of a development } \\
\text { impact on the level of intellectual political members of the community }\end{array}$ & 3.72 & .966 & high \\
\hline Political Dimension & 3.7874 & .57187 & high \\
\hline
\end{tabular}

Last but not least for the third dimension of political development and its relation with culture which the results of the analysis of the dimension that consist of 12 questions indicates a high level of mean equal to 3.78 at Std. Deviation is closed to 0.57187 which indicates a close relationship between culture and political development, especially after several changes in recent royal decisions.

This is illustrated by the results of the questionnaire and questions related to the empowerment of women and women driving car. In addition to the integration of women in many political matters.

The following table shows the results of multiple regression analysis to assess the role of culture in achieving sustainable development through the hypothesis.

Table 5. Multi regression results

\begin{tabular}{lclllc}
\hline \multicolumn{1}{c}{ Variables } & $\mathrm{R}^{2}$ & Adjusted R $^{2}$ & Std Error of Estimate & T test & Sig \\
\hline Economic Development & 0.99 & 0.99 & 0.05077 & 19.9 & 0.000 \\
Social Development & 0.98 & 0.97 & 0.9053 & 17.2 & 0.000 \\
Political Development & 0.98 & 0.98 & 0.6479 & 26.1 & 0.000 \\
\hline
\end{tabular}

\subsection{Analysis of Hypothesizes}

The table above indicates an important role for the independent variable of culture and its relationship with the dependent variable of economic development as the first hypothesis. Where the $\mathrm{T}$ test is equal to (19.9) at a significant level is closed to (0.000). This is less than the significant level at 0.05 which leads to rejection of the zero hypothesis and acceptance of the alternative hypothesis.

As well as the second hypothesis that indicates there is relationship between culture and social development 
where the $\mathrm{T}$ test is equal to (17.2) at significant 0.000 which determine to accept alternative hypothesis instead of zero hypothesis. Also, the third hypothesis that tests the relation between culture and political development where the $\mathrm{T}$ test is equal to (26.1) at significant level 0.000 indicating rejection of zero hypothesis and acceptance of alternative hypothesis. The models had ability to test and analyze the assumptions of the study

Table 6. Hypothesis result

\begin{tabular}{|c|c|c|}
\hline Item & Hypothesis & .Result \\
\hline \multirow[t]{2}{*}{1} & H0: There is no significant relationship between culture and economic development. & Reject \\
\hline & H1: There is significant relationship between culture and economic development. & Accept \\
\hline \multirow[t]{2}{*}{2} & H0: There is no relationship between culture and social development. & Reject \\
\hline & H1: There is relationship between the level of culture and social development. & Accept \\
\hline \multirow[t]{2}{*}{3} & H0: There is no statistically significant relationship between culture and political development. & Reject \\
\hline & H1 There is statistically significant relationship between culture and political development & Accept \\
\hline
\end{tabular}

\section{Conclusion}

Individuals' cultures and their social, economic trends contribute to prove of different factors of development. Culture is the aggregate methods that human resources know have it and had ability to live with it. It affects the economic behavior in terms of consumption and production. It adds positively on the social and economic performance of nations. Even at the political level, culture plays an important role in the formulation and implementation of political decisions.

We can say that the cultural diversity is the base of the renaissance of nations. From my point of view any neglect of societal intellectual change and the development of its culture will adversely affect development. Nowadays, there are clear changes in the culture of consumption of the Saudi citizen, especially after the crisis of low oil prices after the austerity procedures that followed by the princess Mohamed bin Salman. We can also say that culture has an important impact in reducing the luxury consumption of what was earlier happen in ancient times.

The economic culture has become a trend that will not stop, especially the knowledge-based and creative economies. There is a steady increase in the growing economic factors in culture and there is an increase in the cultural factors in the economy. This means that the Saudi economy will not progress without a development in culture. According to the 2030 Vision and the decisions of the promising leadership of king Salman and his son prince Mohammed bin Salman and I see this generation is trying to build a promising future access to cultural change.

Last but not least, from my point of view, cultural diversity will have a great impact on sustainable development in Saudi Arabia. According to the sample of responses is fully covered by the questionnaire. But some old ideas and beliefs still oscillate between acceptance and disapproval because of their old beliefs.

In addition, culture is one of the pillars of economic development. It has a role in generating value added and job opportunities of significant importance in the economy. In particular tourist attractions of the Kingdom of Saudi Arabia

Briefly, we can point out that culture is the starting point for a new stage in the development of societies based on quality of life and creativity. Saudi Arabia must ensure the balance of cultural development and the need to invest in cultural infrastructure, artistic production and creative education.

\section{Recommendation}

- There is a need to focus on promoting cultural development of urban areas and promoting cultural tourism.

- There is a need to rely on cultural industries and also creative industries (economic activities) related to arts and culture.

- Government should support culture projects.

- Expand the concept of participation in various fields, especially cultural fields.

- Enhancing the community orientation towards cultural projects and artistic production. 
- Saudi Arabia must be investing in the long term in cultural projects that will have a developmental role.

- Saudi Arabia must establish a budget for spending on cultural development.

- Saudi Arabia must establish a Ministry of Culture that will take care of various cultural issues in all its dimensions.

- The country should give importance of cultural projects that will generate employment opportunities and will diverse the economy.

\section{References}

Allen, S. (2005). Cultural-Products Industries and Urban Economic Development. Retrieved from https://www.researchgate.net/publication/23749755

Andrew, M. et al. (2009). Marketing Culture, Psychology Wellness, Ethical Climate, Service Performance and Loyalty. Journal of Business and Retail Management Research (JBRMR), 3(2). Retrieved from http://www.jbrmr.com/

Dana, I. (2011). A Culture of Human Rights and the Right to Culture. Journal for Communication and Culture. Retrieved from http://www.jcc.icc.org.ro/

EDURC. (1997). (Eurocities Economic Development and Regeneration Committee), Growth Sectors in European Cities, Munich.

Florida, R. (2002). The rise of the creative class: and how it's transforming work, leisure, community and everyday life. Basic books, New York.

Gavrilescu, L., \& Barbul, C. (2010). Assessment of the organizational culture of the country emergency hospital. Annals of the University of Oradea: Economic Science.

Godwin, O. (2015). Towards a New Philosophy of Language, Culture and Literacy in Nigeria for National Development. Open Journal of Philosophy, 5, 459-470. Retrieved from http://www.scirp.org/journal/

Iyaji, A., \& Gomment, T. I. (2011). Culture and Development: An Exposition of the Interconnectivity (A Review Article). Current Research Journal of Social Sciences, 3(2), 50-53.

Jim, G. et al. (1996). The effect of cultural values on economic development. American Journal of Political Science. Retrieved from https://www.jstor.org/stable/2111786

Jolanta, C.-G. (2011). Economical Aspects of folk culture as an element of balanced Regional Development. Journal of Agribusiness and Rural Development.

Joseph, A. F. et al. (2013). Culture Matters: A Test of Rationality on Economic Growth. Asian Social Science, 9(9).

Kgosietsile, M. (2012). Safeguarding Cultural Heritage as a Strategy for Development in the 21st Century. International Journal of Economic Development Research and Investment, 3(2).

Lamsal, A. K. (2013). Culture and country towards child right in Nepal. A Research Journal of Culture and Society. https://doi.org/10.3126/researcher.v1i1.8369

Obiegbu, L. (2016). Language and Culture: Nigerian Perspective. African Journals Online. Retrieved from https://www.ajol.info/

Okoh, L., \& Ekane, O. R. (2011). Impact assessment of the role of Nigerian stock exchange on the economic development of Nigeria. International Journal of Economic Development Research and Investment, 2(1).

Olayinka, A. (2012). The Ligaments of Culture and Development in Nigeria. International Journal of Applied Sociology.

Petrakis, P. E. (2011). Cultural Background and Economic Development Indicators: European South Vs European North. Retrieved from http://www.SciRP.org/journal/me

Ramirez, L. F. et al. (2016). Culture, Government and Development in South Korea. Asian Culture and History. Retrieved from http://ccsenet.org/ach

Shao, C. Y. (2009). Research on Evaluation Index System of Enterprise Innovation Culture Based on Sustainable Development. Journal of Sustainable Development.

Stöber, B. (2011). Fixed Links and Vague Discourses About Culture and the Making of Cross-border Region. Culture Unbound: Journal of Current Cultural Research. Retrieved from http://www.cultureunbound.ep.liu.se/ 
Sviatlana, B. (2010). Innovations as a development factor for the contemporary culture in belarus. Perspectives of Innovations, Economics \& Business, 5(2).

Tawfik, E.-N. et al. (2013). The impact of leadership behavior and organizational culture on job satisfaction and its relationship among organizational commitment and turnover intentions. A case study on an Egyptian company. Journal of Business \& Retail Management Research, 7(2). Retrieved from http://www.jbrmr.com/

Titan, E. et al. (2008). The impact of cultural-creative industries on the economic growth-a quantitative approach. Retrieved from http://steconomice.uoradea.ro/anale/en_index.html

Tom, O. (2009). What's the Use of Culture? Journal of Current Cultural Research.

Xiufang, L. (2015). Minority Regional Tourism Development and the Refactoring of Minority Culture. Retrieved from http://www.scirp.org/journal/jss

Yan, L. (2009). Analysis of Culture and Buyer Behavior in Chinese Market. Asian Culture and History.

Yang, Y. (2013). Study of the Development of Youth Culture under the Background of Advanced Culture. Retrieved from http://www.scirp.org/journal/sm

Zuofa, C. C. (2006). Women and Culture in a Globalized World: Educational Implication in Nigeria. Journal of Nigerian Languages and Culture, 8. Retrieved from www.scirp.org/

Note

Note 1. http:// www.cese.ma

\section{Copyrights}

Copyright for this article is retained by the author(s), with first publication rights granted to the journal.

This is an open-access article distributed under the terms and conditions of the Creative Commons Attribution license (http://creativecommons.org/licenses/by/4.0/). 